\title{
EFFECT OF POLYMER CONCENTRATION ON INITIAL MODEL PARAMETERS AND RHEOLOGICAL PROPERTIES OF BENTONITE/POLYMER DRILLING FLUID
}

\author{
Nguyen Huu Truong \\ PetroVietnam University \\ E-mail: truongnh@pvu.edu.vn
}

Received: 2-3-2016

\begin{abstract}
Bentonite/polymer fluid systems are often used to drill wells in the top of basement formation of the continental shelf of Vietnam, where the formation pressure gradient gradually reaches to subnormal pressure. Thus, bentonite/polymer drilling fluids with the mud weight from $8.4 \mathrm{ppg}$ to $8.5 \mathrm{ppg}$ are able to drill this section. In this study, the effect of the polymer concentrations on the initial parameters of the drilling fluid models have been presented in the detail of the article. Moreover, non-Newtonian fluid models often describe the behavior of fluids, which the models as Bingham plastic, Power law, Casson model, Herschel Bulkley, and Robertson-Stiff have mentioned. To determine the initial parameters of the models, the mathematical least square method is used. The database was gathered from 6 dial readings as $600 \mathrm{rpm}, 300 \mathrm{rpm}, 200 \mathrm{rpm}$, $6 \mathrm{rpm}$ and $3 \mathrm{rpm}$ of API 13B standard. Finally, the ANOVA table analysis shows that the confident coefficient reaches $100 \%$, which has been demonstrated to be highly significant by the models.
\end{abstract}

Keywords: Polymer concentration, initial model parameter, bentonite/polymer drilling fluid.

\section{INTRODUCTION}

The main reasons for application of the rheological properties and initial model parameters for investigating the fluid behavior by increasing polymer concentration during the experiment are to solve the hole cleaning in order to transport the cuttings from the bottom hole to the surface and hole erosion, suspension of cuttings, hydraulic calculation operation and treated fluid to drill well in the basement formation. The petroleum industry has involved the two concepts of shear rate and shear stress with the mathematical relationship being described by the flow models of drilling fluids. Moreover, the shear rate and shear stress are two basic concepts of measurement to define the type of fluid flow. In the previous research, many authors have not mentioned the study on the effect of the particular polymer concentration the rheological properties and initial model parameters as shear stresses. The study deals with guar gum, xanthan gum and carboxylmethyl cellulose (CMC) and implemented their behavior of drilling fluid as reference in [1] and filtration control. The earliest study on the xanthan gum was implemented by Salamone et al., (1980) [2]. Its research was shown that many polymers with polysaccharides were used in the drilling fluid. In 1960, guar was found from a bean that was added to water thickeners and fluid viscosities and it is often used in the petroleum industry today. In this study, the paper has presented the effect of guar polymer concentration from 0.5 pounds per barrel to 1.3 pounds per barrel on 
the initial model parameters as initial shear stress and rheological properties of bentonite/polymer drilling fluid.

\section{THE CONDITION OF YIELD POINT STRESS FOR CUTTINGS TRANSPORT AND CUTTINGS SUSPENSION IN DRILLING FLUIDS}

In order to understand the shear stress and shear rate, it is necessary to consider fluid contained between large parallel plates of area $A$, which are separated by small distance $L$. The upper plate in initially in rest and set that plate is motion with one direction at a constant velocity, $v$. The force required to keep the upper plate moving at a constant velocity dividing the plate area is called the shear stress and the ratio of the velocity dividing small distance, $L$, is called the shear rate. The magnitude of the force $F$ is determined by the model. According to the initial shear stress, the minimum force is required to keep the motion of the upper plates.

$$
\frac{F}{A}=\mu \times \frac{v}{L} \quad \text { or } \quad \tau=\mu \times \gamma
$$

The condition of cuttings transport from the bottom hole to the surface:

Mud velocity $\left(V_{a}\right)$ in the annulus depends on: Pump flow rate, Annular geometry.

Cuttings settling velocity $\left(V_{s}\right)$ in the annulus depends on: Mud properties, Rheology as mud viscosity (cp), Mud density (ppg), Cutting diameter, Cuttings density (ppg), Cutting shape and size.

Accordingly, the condition for cuttings transport to the surface.

$$
\frac{V_{a}-V_{s}}{V_{a}}>50 \%
$$

The condition of cuttings suspension in drilling fluid in the annulus depends on: Yield strength of mud; rheological behavior; gel strength.

The tangent of normal stress $\left(\tau_{c u t}\right)$ due to cutting weight depends on: Cutting diameter $\left(d_{c}\right)$, Cutting density $\left(\rho_{c}\right)$, Cutting shape, Mud density $\left(\rho_{m}\right)$, ppg.

$$
\tau_{c u t}=\frac{d_{c}\left(\rho_{c}-\rho_{m}\right)}{6}
$$

According to the condition of cuttings transport and cuttings suspension in drilling mud:

$$
\tau_{y}>\frac{d_{c}\left(\rho_{c}-\rho_{m}\right)}{6}
$$

The modeling of cuttings transport and cuttings suspension in drilling fluid is shown in the figure 1 .

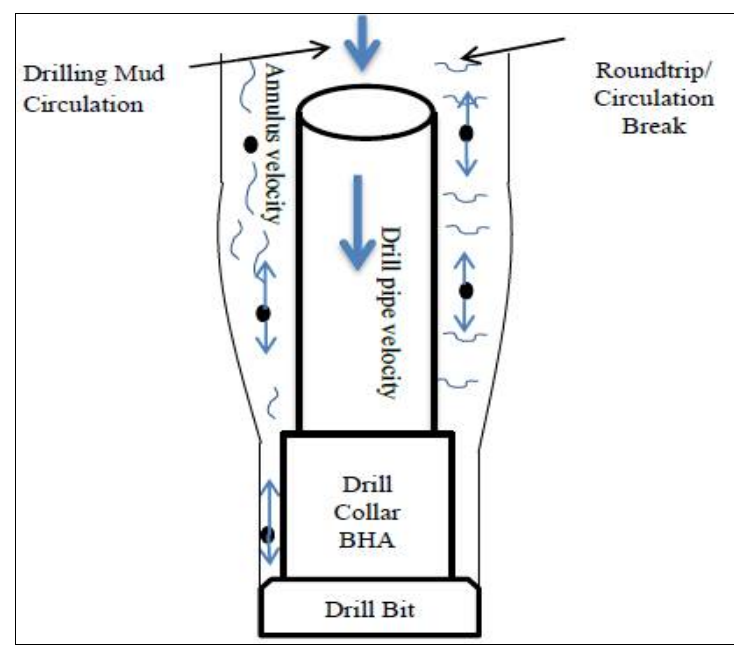

Fig. 1. The modeling of cutting transport from bottom hole to the surface and performing the cutting suspension in drilling fluid

\section{FLOW REGIME AND CRITICAL REYNOLDS NUMBER IN THE ANNULUS}

Table 1. Critical Reynolds number for Newtonian fluid

\begin{tabular}{ccc}
\hline Re & Flow Regime \\
\hline$<2,000$ & & Laminar flow \\
2,000 to 4,000 & & Transitional flow \\
$>4,000$ & Turbulent flow \\
\hline
\end{tabular}

In order to determine the flow regime in the annulus, the value obtained for the Reynolds number based on the flow behavior index (n) is 
compared with the following figures, based upon experiments conducted by observing the flow of a Newtonian fluid (in this case water) through a circular pipe as table 1 .

However, as drilling fluids do not follow the properties of a true Newtonian fluid, the equations below have been developed in order to determine the critical Reynolds number at which the flow regime is:

$$
\text { Laminar flow: } \operatorname{Re}_{\mathrm{c}}=3470-1370 \mathrm{n}
$$

Transitional flow:

$$
3470 \text { - 1370n }<\operatorname{Re}_{\mathrm{c}}<4270-1370 \mathrm{n}
$$

Turbulent flow: $\operatorname{Re}_{\mathrm{c}}=4270-1370 \mathrm{n}$

Where: $\mathrm{Re}_{\mathrm{c}}$ is the critical Reynolds number in an annular section, $\mathrm{n}=$ power law constant for the annulus.

\section{LINEAR LEAST SQUARE METHOD}

The least square method is a procedure that requires some calculus and linear algebra in order to determine what is the "best fit" line with the data. Of course, the method needs to quantify what we mean by "best fit", which will be required, a brief review of some probability and statistics as the given data $\left\{\left(x_{1}\right.\right.$, $\left.\left.y_{1}\right), \ldots,\left(x_{N}, y_{N}\right)\right\}$; the solutions can define the error that is associated with the equation: $y=$ $a x+b$.

Solution for:

$$
E(a, b)=\sum_{n=1}^{N}\left(y_{n}-\left(a x_{n}+b\right)\right)^{2}
$$

The aim is to find the values of two unknowns $a$ and $b$ from equation which minimize the error. Integrating two sided equation following $a$ and $b$.

Differentiating $E(a, b)$ yields:

$$
\left\{\begin{array} { c } 
{ \sum _ { n = 1 } ^ { N } 2 ( y _ { n } - ( a x _ { n } + b ) ) \times ( - x _ { n } ) = 0 } \\
{ \sum _ { n = 1 } ^ { N } 2 ( y _ { n } - ( a x _ { n } + b ) ) \times 1 = 0 }
\end{array} \Rightarrow \left\{\begin{array}{c}
a \sum_{n=1}^{N} x_{n}^{2}+b \sum_{n=1}^{N} x_{n}=0 \\
a \sum_{n=1}^{N} x_{n}+b \sum_{n=1}^{N} 1=0
\end{array}\right.\right.
$$

Therefore, two unknowns $a$ and $b$ are determined by the matrix below:

$$
\left(\begin{array}{l}
a \\
b
\end{array}\right)=\left(\begin{array}{cc}
\sum_{n=1}^{N} x_{n}^{2} & \sum_{n=1}^{N} x_{n} \\
\sum_{n=1}^{N} x_{n} & \sum_{n=1}^{N} 1
\end{array}\right)^{-1} \times\left(\begin{array}{c}
\sum_{n=1}^{N} x_{n} y_{n} \\
\sum_{n=1}^{N} y_{n}
\end{array}\right)
$$

The mean observed data of $\bar{y}$ is calculated as:

$$
\bar{y}=\frac{1}{n} \sum_{n=1}^{N} y_{n} .
$$

The confident coefficient is given by equation below:

$$
\begin{aligned}
R^{2} & =\frac{S S_{\text {reg }}}{S S_{\text {total }}}=\frac{\sum_{n=1}^{N}\left(f_{n}-\bar{y}\right)^{2}}{\sum_{n=1}^{N}\left(y_{n}-\bar{y}\right)^{\wedge 2}} \\
& =\frac{\sum_{n=1}^{N}\left(f_{n}-\bar{y}\right)^{2}}{\sum_{n=1}^{N}\left(y_{n}-\bar{y}\right)^{2}}
\end{aligned}
$$

The adjusted $R^{2}$ is determined by equation:

$$
\bar{R}^{2}=1-\left(1-R^{2}\right) \times \frac{n-1}{n-p-1}
$$

Where: $p$ value is the total number of explanatory variables in the model without constant variable. Of course, if the $p$ value reaches 0.001 , the model is highly significant.

\section{BINGHAM PLASTIC MODEL}

According to Bourgoyne et al., (1986) [3], the Bingham plastic model and Ostwald DeWaele model (or commonly known as the Power law model) are the two earliest models, which are often used in describing the rheological properties of drilling fluids and cement slurries in the petroleum industry. Thus, the Bingham plastic model can be performed at the following formula:

$$
\tau=\tau_{o}+K \gamma
$$

Where the parameters are constrained of $\tau_{o}>0$ and $K>0$. The model is a linear order to determine the parameters by using regression 


\section{Effect of polymer concentration on initial...}

analysis. Thus, the uses of the model have recognized the advantages of the Bingham plastic model that will provide the initial value of the fluids to start with having a flow that is referred to as the Bingham yield point $\left(\tau_{o}\right)$. Recently, many studies on more complex fluids have shown that very few researches have suggested that model to describe the rheological behavior of drilling/completion fluids or cement slurries, especially in low shear rates [4]. Thus, the initial problem in the Bingham plastic model's failure is to conform to the complex fluid behavior with the relationship between the shear stress $(\tau)$ and shear rate $(\gamma)$ and it is frequently the results of the unreality with the initial high value of shear stress, $\tau_{o}$.

\section{POWER LAW MODEL}

In order to overcome this linear relationship between the shear stress and the shear rate, many fluid experts have referred to OstwaldDe-Waele model (or mostly known as Power law model). The Ostwald-De-Waele model can be performed in the following equation:

$$
\tau=K \gamma^{n}
$$

Where the parameters are constrained with $K>$ 0 and $0<\mathrm{n}<1$.

The above model is considerably more convenient than the Bingham plastic model because that model presents low shear stress by non-linear shear stress model and it is a power law model. With the absence of the initial value of shear stress, $\tau_{\mathrm{o}}$, the model is proven with low shear stress in the low shear rate.

\section{CASSON MODEL}

Another model commonly used to describe the rheological behavior of the complex fluid in the petroleum industry is Casson model [4]. Therefore, the Casson model is often given by the equation below:

$$
\tau=\left(\sqrt{\tau_{o c}}+\sqrt{\mu_{o c} \gamma}\right)^{2}
$$

These parameters are constrained with $\tau_{o c}>0$ and $\mu_{o c}>0$.
The model is initially generated to perform the rheological properties of inks and paints. However, many experts in the drilling mud of petroleum industry have also used it to evaluate the drilling fluid behavior; especially, in the drilling fluid which is primarily bentonite suspension.

\section{ROBERTSON STIFF MODEL}

In order to evaluate the better of the complex fluid's viscoelastic behavior, the other type of rheological model, namely RobertsonStiff model was proposed by (Robertson and Stiff, (1976)) [5]. Besides the Casson model, the three-parameter Robertson-Stiff model has also been proven to be appropriate to describe the behavior of drilling fluids with betonite suspension. It has also been obtained that this model has also successfully been used to perform the fluid rheology of cement slurries. The model of Robertson-Stiff can be expressed in the following equation:

$$
\tau=A(C+\gamma)^{B}
$$

Where the constant parameters of $K, C, B$ are constrained with $A>0,0<B<1$, and $C \geq 0$.

The constant parameter $\mathrm{C}$ is calculated in a way as:

$$
C=\left(\gamma_{\min } \gamma_{\max }-\gamma^{2}\right) /\left(2 \gamma-\gamma_{\min }-\gamma_{\max }\right)
$$

Where the value $\gamma$ is the shear rate corresponding to the geometric mean of the shear stress, $\tau$.

$$
\tau=\left(\tau_{\min } \times \tau_{\max }\right)^{0.5}
$$

\section{HERSCHEL-BULKLEY MODEL}

The Herschel-Bulkley model [6] is a combination of Bingham plastic model and power law model, which provides three parameters to perform the relationship between shear rate and shear stress [6]. After the research, the model had widely shown that the rheological behavior of the model was applied in many types of drilling fluid, drilling fluid for well completion and cement slurries can be achieved by the Herschel-Bulkley model [7]. Here the Herschel-Bulkley model is given by following equation: 


$$
\tau=\tau_{o}+K \gamma^{n}
$$

Where parameters are constrained of $K>0,0<$ $\mathrm{n}<1$, and $\tau_{o} \geq 0$.

Three parameters have been determined, only one initial parameter of $\tau_{o}$ is required to calculate value by Gücüyener, (1992) [1, 2] method. Here is one method for calculate this initial parameter:

$$
\tau_{o}=\left(\tau^{2}-\tau_{\min } \tau_{\max }\right) /\left(2 \tau-\tau_{\min }-\tau_{\max }\right)
$$

In which, the shear stress value, $\tau$, is corresponding to the geometric mean of the shear rate, $\gamma$.

$$
\gamma=\left(\gamma_{\min } \times \gamma_{\max }\right)^{0.5}
$$

\section{DRILLING FLUID SAMPLES}

The fluid samples were prepared by mixing chemical compositions as guar gum polymer, PAC (polyanionic cellulose), biocide, caustic soda, soda ash with bentonite concentration of 20 pounds per barrel in specified experiment and other variances were changed during the study. In which, guar polymer mainly carries the capacity of the fluid system and also controls the yield point, plastic viscosity, gel strength in 10 seconds by adding that polymer concentration to fluid system during experiments. PAC polymer has main purpose to support the polymer inhibition of the drilling fluid system which together helps to control the filtration rate through the formation with the differential pressure between pore pressure and hydrostatic pressure. Biocide is mainly implemented to protect the fluid system without damage in the environment condition. Caustic soda is provided to control the $\mathrm{pH}$ scale from 8 to 9 . Soda ash functions as keeping the water in good condition. Finally, bentonite is mainly provided to make the fluid structure and also has purpose as carrying the fluid viscosity. The samples of bentonite polymer fluids were

\begin{tabular}{|c|c|c|c|}
\hline \multirow{2}{*}{ Composition } & Sample 1 & Sample 2 & Samples 3 \\
\hline & Concentration (gram) & Concentration(gram) & Concentration (gram) \\
\hline Bentonite & 11 & 11 & 11 \\
\hline Guar Gum Polymer & 0.5 & 1 & 1.3 \\
\hline PAC-LV & 0.5 & 0.5 & 0.5 \\
\hline Caustic soda & 0.5 & 0.5 & 0.5 \\
\hline Soda ash & 0.5 & 0.5 & 0.5 \\
\hline Biocide & 0.5 & 0.5 & 0.5 \\
\hline Water & 350 & 350 & 350 \\
\hline
\end{tabular}
shown in the table 2.

Table 2. Preparing compositions of fluid samples of bentonite polymer fluid

\section{EQUIPMENT AND PROCEDURE}



Fig. 2. Fann V-35 Viscometer for measuring the rheological properties of drilling fluid
The equipment and procedure of experiments are followed of viscosity and gel strength, rheological properties of drilling fluid calculations and measurements are based on the standard API RB 13B dictated to the Viscometer (Fann-35) as seen in the figure 2, which is used to measure the viscosity and gel strength of the fluid samples. During the experiments, drilling fluid will be contained in the annular space between two concentric motors. The outer cylinder or rotor sleeve is running at constant speed (rpm). The instrument constants have determined the plastic viscosity and yield strength of the results from dial readings of $300 \mathrm{rpm}, 600 \mathrm{rpm}$. To obtain the database, the six Fann viscometer 
dial reading is to gather these shear rate as $600 \mathrm{rpm}, 300 \mathrm{rpm}, 200 \mathrm{rpm}, 100 \mathrm{rpm}, 6 \mathrm{rpm}$ and $3 \mathrm{rpm}$.

\section{EFFECT OF POLYMER CONCENTRA- TION ON INITIAL PARAMETERS OF MODELS AND RHEOLOGICAL PROP- ERTIES OF DRILLING FLUID}

The table 3 and table 5 show the initial parameters as initial shear stress, consistency index $(\mathrm{K})$ of power law, Bingham model, Casson model, Robertson-Stiff model and Herschel-Bulkley model and the results illustrate that the increase in guar concentration of 0.5 pounds per barrel to $1.3 \mathrm{pbb}$ of each experiment makes the initial shear stress increase from $33.8 \mathrm{lbf} / 100 \mathrm{ft}^{2}, 40.4 \mathrm{lbf} / 100 \mathrm{ft}^{2}$ to $44.8 \mathrm{lbf} / 100 \mathrm{ft}^{2}$ and the consistency index increase from $5.84 \mathrm{lbf} / \mathrm{ft}^{2}$ to $8.87 \mathrm{lbf} / \mathrm{ft}^{2}$ of the Bingham model. In order to demonstrate the effect of the guar polymer concentration on the initial parameters of the Casson model, the laboratory experiments show that the initial shear stress by calculations and measurements also increases from $23.5225 \mathrm{lbf} / 100 \mathrm{ft}^{2}$ to 31.47 $\mathrm{lbf} / 100 \mathrm{ft}^{2}$ due to more polymer concentration added to drilling fluid as more molecular weight added to the drilling fluid system, which leads to the increase of the viscosity as the increase of the force resistance. Simultaneously the initial parameters of Robertson-Stiff, Herschel-Bulkley models are estimated. The initial parameter as shear stress of HerschelBulkley increases from $22.86 \mathrm{lbf} / 100 \mathrm{ft}^{2}$ to $28.56 \mathrm{lbf} / 100 \mathrm{ft}^{2}$. The rheological properties as plastic viscosity (PV) and yield strength (YP) increase in which the plastic viscosity (PV) increases from $26 \mathrm{cp}, 30 \mathrm{cp}, 32 \mathrm{cp}$ and these yield strengths increase from $40 \mathrm{lbf} / 100 \mathrm{ft}^{2}, 56$ $\mathrm{lbf} / 100 \mathrm{ft}^{2}$, and $58 \mathrm{lbf} / 100 \mathrm{ft}^{2}$ by adding guar polymer as 0.5 gram, 1 gram, and 1.3 gram of drilling fluid, respectively. For explanation, the initial shear stress $\left(\tau_{o}\right)$ increases in all models by increasing guar polymer added to drilling fluid, leading to the increase of drilling fluid viscosity. Therefore, the minimum force required for motion of the upper plates of fluid is higher. For comparison, these shear stresses at each shear rate of the models are shown in the figure 3 , figure 4 , and figure 5 .

Table 3. Data gathered and calculated from fluid sample 3

\begin{tabular}{|c|c|c|c|c|c|c|c|}
\hline $\begin{array}{l}\text { Shear } \\
\text { rate } \\
\left(\mathbf{s}^{-1}\right)\end{array}$ & $\begin{array}{c}\text { Fann } \\
\text { degree } \\
\left(\mathrm{lbf} / 100 \mathrm{ft}^{2}\right)\end{array}$ & $\begin{array}{c}\text { Shear } \\
\text { stress } \\
\left(\mathrm{lbf} / 100 \mathrm{ft}^{2}\right)\end{array}$ & $\begin{array}{l}\text { Power law } \\
\left(\mathrm{lbf} / 100 \mathrm{ft}^{2}\right)\end{array}$ & $\begin{array}{c}\text { Bingham } \\
\text { plastic } \\
\left(\mathrm{lbf} / 100 \mathrm{ft}^{2}\right)\end{array}$ & $\begin{array}{c}\text { Casson } \\
\text { model } \\
\left(\mathrm{lbf} / \mathbf{1 0 0} \mathrm{ft}^{2}\right)\end{array}$ & 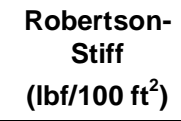 & $\begin{array}{l}\text { Herschel- } \\
\text { Bulkley } \\
\left(\mathrm{lbf} / 100 \mathrm{ft}^{2}\right)\end{array}$ \\
\hline 1022 & 80 & 85.2 & 83.42 & 93.49 & 93.65 & 88.74 & 103.90 \\
\hline 511 & 66 & 70.3 & 70.49 & 63.64 & 68.284 & 71.29 & 71.92 \\
\hline 341 & 60 & 63.9 & 63.89 & 53.71 & 58.35 & 62.84 & 59.45 \\
\hline 170 & 50 & 53.3 & 53.95 & 43.73 & 46.50 & 50.89 & 45.00 \\
\hline 10.22 & 24 & 25.6 & 27.24 & 34.40 & 28.44 & 26.46 & 25.75 \\
\hline \multirow[t]{4}{*}{5.11} & \multirow[t]{4}{*}{23} & \multirow[t]{4}{*}{24.5} & 23.02 & 34.1 & 26.95 & 24.51 & 24.61 \\
\hline & & & $n=0.243$ & $\tau_{o}=33.8$ & $\tau_{o}=23.52$ & $A=9.49$ & $\tau_{o}=22.86$ \\
\hline & & & $K=15.487$ & $K=0.0584$ & & $B=0.322$ & $\mathrm{n}=0.724$ \\
\hline & & & & & $0.0<0$ & $C=13.95$ & $\mathrm{~K}=0.54$ \\
\hline \multicolumn{2}{|c|}{ Gel $10 \mathrm{~s}=20$} & & $R^{2}=99.4$ & $R^{2}=84.1$ & $R^{2}=95.5$ & $R^{2}=99.6$ & $R^{2}=98.5$ \\
\hline \multicolumn{2}{|c|}{$P V(c p)=26$} & & $\mathrm{R}^{2} \mathrm{adj}=99.3$ & $\mathrm{R}^{2} \mathrm{adj}=80.2$ & $\mathrm{R}^{2} \mathrm{adj}=94.4$ & $R^{2} \operatorname{adj}=99.5$ & $\mathrm{R}^{2} \mathrm{adj}=98.1$ \\
\hline YP (lb/ & $\left.00 \mathrm{ft}^{2}\right)=40$ & & & & & & \\
\hline
\end{tabular}

Table 4. These new predicted models obtained from experimental fluid sample 1

\begin{tabular}{|c|c|c|c|c|}
\hline $\begin{array}{l}\text { Power law } \\
\left(\mathrm{lbf} / 100 \mathrm{ft}^{2}\right)\end{array}$ & $\begin{array}{c}\text { Bingham plastic } \\
\left(\mathrm{lbf} / 100 \mathrm{ft}^{2}\right)\end{array}$ & $\begin{array}{c}\text { Casson Model } \\
\left(\mathrm{lbf} / 100 \mathrm{ft}^{2}\right)\end{array}$ & $\begin{array}{c}\text { Robertson-Stiff } \\
\left(\mathrm{lbf} / 100 \mathrm{ft}^{2}\right)\end{array}$ & $\begin{array}{l}\text { Herschel-Bulkley } \\
\left(\mathrm{lbf} / 100 \mathrm{ft}^{2}\right)\end{array}$ \\
\hline$\tau=15.4871 \gamma^{0.243}$ & $\tau=33.8+0.0584 \gamma$ & $23.52+\sqrt{0.023 \gamma})^{\frac{1}{2}}$ & $\tau=9.49(13.95+\gamma)^{0.322}$ & $\tau=22.86+0.54 \gamma^{0.724}$ \\
\hline
\end{tabular}


Table 5. Data gathered and calculated from fluid sample 2

\begin{tabular}{|c|c|c|c|c|c|c|c|}
\hline $\begin{array}{l}\text { Shear } \\
\text { rate } \\
\left(\mathrm{s}^{-1}\right)\end{array}$ & $\begin{array}{c}\text { Fann } \\
\text { degree } \\
\left(\mathrm{lbf} / 100 \mathrm{ft}^{2}\right)\end{array}$ & $\begin{array}{c}\text { Shear } \\
\text { stress } \\
\left(\mathrm{lb} / 100 \mathrm{ft}^{2}\right)\end{array}$ & $\begin{array}{l}\text { Power law } \\
\left(\mathrm{lbf} / 100 \mathrm{ft}^{2}\right)\end{array}$ & $\begin{array}{c}\text { Bingham } \\
\text { plastic } \\
\left(\mathrm{lbf} / 100 \mathrm{ft}^{2}\right)\end{array}$ & $\begin{array}{c}\text { Casson } \\
\text { model } \\
\left(\mathrm{lbf} / 100 \mathrm{ft}^{2}\right)\end{array}$ & $\begin{array}{c}\text { Robertson- } \\
\text { Stiff } \\
\left(\mathrm{lbf} / 100 \mathrm{ft}^{2}\right)\end{array}$ & $\begin{array}{l}\text { Herschel- } \\
\text { Bulkley } \\
\left(\mathrm{lbf} / 100 \mathrm{ft}^{2}\right)\end{array}$ \\
\hline 1022 & 116 & 123.5 & 110.21 & 131.051 & 127.87 & 120.91 & 129.87 \\
\hline 511 & 86 & 91.6 & 92.67 & 85.73 & 91.34 & 93.45 & 94.20 \\
\hline 341 & 76 & 80.9 & 83.74 & 70.62 & 77.12 & 80.70 & 79.39 \\
\hline 170 & 59 & 62.84 & 70.41 & 55.51 & 60.38 & 63.49 & 61.23 \\
\hline 10.22 & 34 & 36.2 & 34.85 & 41.31 & 35.14 & 33.48 & 33.14 \\
\hline 5.11 & 28 & 29.8 & $\begin{array}{c}29.31 \\
n=0.250 \\
K=19.5\end{array}$ & $\begin{array}{c}40.85 \\
\tau_{o}=40.4 \\
\mathrm{~K}=0.0887\end{array}$ & $\begin{array}{c}33.1 \\
\tau_{o}=28.41 \\
\mu_{o}=0.035\end{array}$ & $\begin{array}{c}31.65 \\
A=8.25 \\
B=0.386 \\
C=27.47\end{array}$ & $\begin{array}{c}31.04 \\
\tau_{o}=27.088 \\
\mathrm{n}=0.615 \\
\mathrm{~K}=1.45\end{array}$ \\
\hline \multicolumn{2}{|c|}{$\begin{array}{l}\text { Gel } 10 \mathrm{~s}=25 \\
\text { PV }(c p)=30 \\
\text { YP }\left(\mathrm{lb} / 100 \mathrm{ft}^{2}\right)=56\end{array}$} & & $\begin{array}{l}R^{2}=98.1 \\
R^{2}-A d j=97.6\end{array}$ & $\begin{array}{l}R^{2}=93.6 \\
R^{2}-A d j=92\end{array}$ & $\begin{array}{l}R^{2}=99.1 \\
R^{2}-A d j=98.9\end{array}$ & $\begin{array}{l}R^{2}=99.3 \\
R^{2} \text { adj }=99.1\end{array}$ & $\begin{array}{l}R^{2}=96.7 \\
R^{2} \text { adj }=95.8\end{array}$ \\
\hline
\end{tabular}

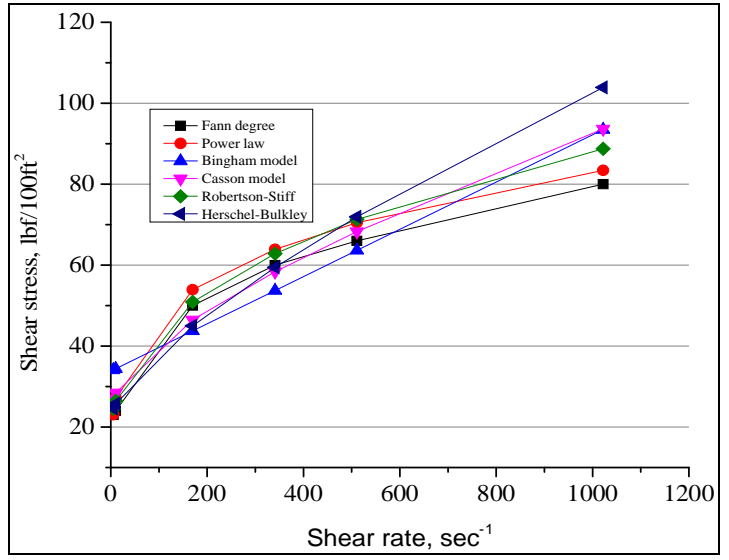

Fig. 3. Comparison of the shear rate and shear stress among the models with sample 1

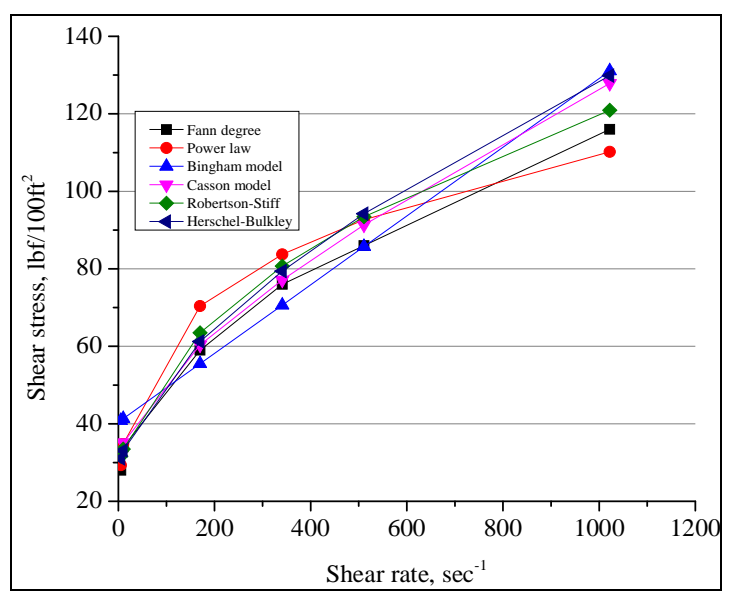

Fig. 4. Comparison of the shear rate and shear stress among the models with sample 2

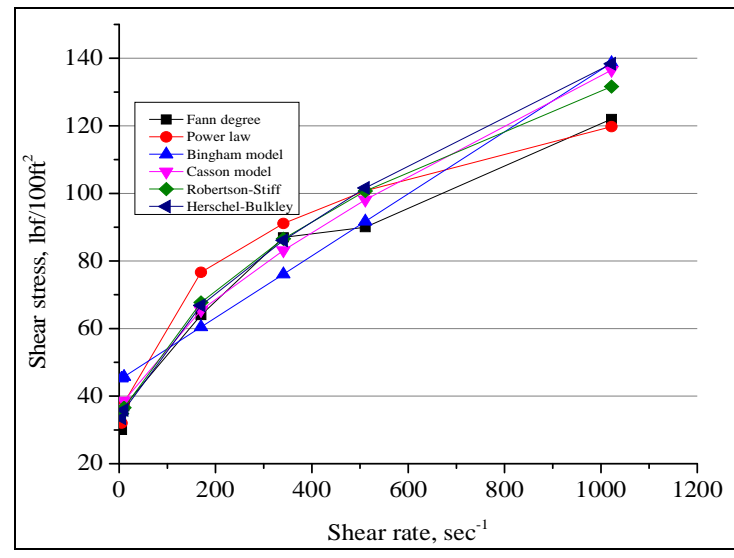

Fig. 5. Comparison of the shear rate and shear stress among the models with sample 3

\section{EFFECT OF POLYMER CONCENTRATION ON GEL STRENGTH IN 10 SECONDS}

Guar polymer is approximately about $2,000,000$ molecular weights and it is also polysaccharide with mannose backbone/ galactose side unit. As seen in the results of the experiments in table 2 and table 3 the gel strength in 10 seconds gradually increases by adding guar polymer concentration of drilling fluid with polymer concentration from 0.5 pounds per barrel to 1.3 pounds per barrel in each experiment. Because guar polymer is a high molecular weight, more polymer concentration results in high viscosity of 
drilling fluid and the increase in gel strength in 10 seconds as shown in the figure 6 .



Fig. 6. Effect of guar polymer concentration on gel strength in 10 seconds

\section{CONCLUSIONS}

The results of this research can be summarized as follows:

The increase in the polymer with polysaccharide as guar added to drilling fluid makes the initial mode parameters and rheological properties as shear stress, gel strength in 10 seconds increase.

The power law model shows the shear stress lower than that of others in each models in the columns.

The least square method is often used to determine the initial model parameters with the confidence coefficient of $100 \%$. Therefore, most models showing in the table 3 , table 5 and table 7 are actually as same in the field.

The Fann 35 viscometer is the best tool to measure the viscosity, shear stress following the API standard.

It is necessary to continue studying the effect of polymer concentration and the interaction between the variables on the initial model parameters and rheological properties of drilling fluid.

The value of the critical Reynolds number is between 2,000 and 4,000, the flow regime in the annulus is the transitional flow regime.

Table 6. These new predicted models obtained from experimental fluid sample 2

\begin{tabular}{|c|c|c|c|c|}
\hline $\begin{array}{l}\text { Power law } \\
\left.\text { (lbf/100 } \mathrm{ft}^{2}\right)\end{array}$ & $\begin{array}{c}\text { Bingham plastic } \\
\left(\mathrm{lbf} / 100 \mathrm{ft}^{2}\right)\end{array}$ & $\begin{array}{l}\text { Casson Model } \\
\left(\mathrm{lbf} / 100 \mathrm{ft}^{2}\right)\end{array}$ & $\begin{array}{l}\text { Robertson-Stiff } \\
\left(\mathrm{lbf} / 100 \mathrm{ft}^{2}\right)\end{array}$ & $\begin{array}{l}\text { Herschel-Bulkley } \\
\left(\mathrm{lbf} / 100 \mathrm{ft}^{2}\right)\end{array}$ \\
\hline$\tau=19.51 \gamma^{0.250}$ & $\tau=40.4+0.0887 \gamma$ & $28.41+\sqrt{0.035 \gamma}$ & $\tau=8.25(27.47+\gamma)^{0.386}$ & $\tau=27.088+1.45 \gamma^{0.615}$ \\
\hline
\end{tabular}

Table 7. Data gathered and calculated from fluid sample

\begin{tabular}{|c|c|c|c|c|c|c|c|}
\hline $\begin{array}{l}\text { Shear } \\
\text { rate } \\
\left(s^{-1}\right)\end{array}$ & $\begin{array}{c}\text { Fann } \\
\text { degree } \\
\left(\mathrm{lbf} / 100 \mathrm{ft}^{2}\right)\end{array}$ & $\begin{array}{c}\text { Shear } \\
\text { stress } \\
\left(\mathrm{lb} / 100 \mathrm{ft}^{2}\right)\end{array}$ & $\begin{array}{c}\text { Power law } \\
\left(\mathrm{lbf} / 100 \mathrm{ft}^{2}\right)\end{array}$ & $\begin{array}{c}\text { Bingham } \\
\text { plastic } \\
\left(\mathrm{lbf} / 100 \mathrm{ft}^{2}\right)\end{array}$ & $\begin{array}{c}\text { Casson } \\
\text { model } \\
\left(\mathrm{lbf} / 100 \mathrm{ft}^{2}\right)\end{array}$ & $\begin{array}{c}\text { Robertson- } \\
\text { Stiff } \\
\left(\mathrm{lbf} / 100 \mathrm{ft}^{2}\right)\end{array}$ & $\begin{array}{c}\text { Herschel- } \\
\text { Bulkley } \\
\left(\mathrm{lbf} / 100 \mathrm{ft}^{2}\right)\end{array}$ \\
\hline 1022 & 122 & 129.9 & 119.76 & 138.62 & 136.52 & 131.62 & 138.36 \\
\hline 511 & 90 & 95.85 & 100.77 & 91.71 & 98.11 & 100.71 & 101.61 \\
\hline 341 & 87 & 92.66 & 91.1 & 76.08 & 83.12 & 86.55 & 86.12 \\
\hline 170 & 64 & 68.2 & 76.65 & 60.43 & 65.44 & 67.73 & 66.85 \\
\hline 10.22 & 37 & 39.4 & 38.04 & 45.74 & 38.66 & 36.58 & 35.90 \\
\hline 5.11 & 30 & 32 & $\begin{array}{c}32.01 \\
n=0.249 \\
K=20.7\end{array}$ & $\begin{array}{c}45.27 \\
\tau_{o}=44.8 \\
\mathrm{~K}=0.0918\end{array}$ & $\begin{array}{c}36.48 \\
\tau_{o}=31.47 \\
\mu_{o}=0.0361\end{array}$ & $\begin{array}{c}34.83 \\
A=7.846 \\
B=0.405 \\
C=23.54\end{array}$ & $\begin{array}{c}33.44 \\
\tau_{o}=28.56 \\
\mathrm{n}=0.588 \\
\mathrm{~K}=1.87\end{array}$ \\
\hline $\begin{array}{l}\text { Gel } 10 s \\
\text { PV (cp) } \\
\text { YP (lb/1 }\end{array}$ & $\begin{array}{l}=27 \\
=32 \\
\left.00 \mathrm{ft}^{2}\right)=58\end{array}$ & & $\begin{array}{l}R^{2}=98.4 \\
R^{2} A d j=98\end{array}$ & $\begin{array}{l}R^{2}=90.7 \\
R^{2}-A d j=88.3\end{array}$ & $\begin{array}{l}R^{2}=97.8 \\
R^{2}-A d j=97.3\end{array}$ & $\begin{array}{l}R^{2}=98.6 \\
R^{2} \text { adj }=98.3\end{array}$ & $\begin{array}{l}R^{2}=96.4 \\
R^{2} \text { adj }=95.5\end{array}$ \\
\hline
\end{tabular}


Table 8. These new predicted models obtained from experimental fluid sample 3

\begin{tabular}{|c|c|c|c|c|}
\hline $\begin{array}{l}\text { Power law } \\
\left(\mathrm{lbf} / 100 \mathrm{ft}^{2}\right)\end{array}$ & $\begin{array}{l}\text { Bingham plastic } \\
\left(\mathrm{lbf} / 100 \mathrm{ft}^{2}\right)\end{array}$ & $\begin{array}{l}\text { Casson Model } \\
\left(\mathrm{lbf} / 100 \mathrm{ft}^{2}\right)\end{array}$ & $\begin{array}{l}\text { Robertson-Stiff } \\
\left(\mathrm{lbf} / 100 \mathrm{ft}^{2}\right)\end{array}$ & $\begin{array}{l}\text { Herschel-Bulkley } \\
\left(\mathrm{lbf} / 100 \mathrm{ft}^{2}\right)\end{array}$ \\
\hline$\tau=20.7 \gamma^{0.249}$ & $\tau=44.8+0.0918 \gamma$ & $\tau=(31.47+\sqrt{0.0361 \gamma})^{\frac{1}{2}}$ & $\tau=7.846(23.54+\gamma)^{0.405}$ & $\tau=28.56+1.87 \gamma^{0.588}$ \\
\hline
\end{tabular}

\section{REFERENCES}

1. Darley, H. C., and Gray, G. R., 1988. Composition and properties of drilling and completion fluids. Gulf Professional Publishing.

2. Salamone, J. C., Clough, S. B., Salamone, A. B., Reid, K. I. G., and Jamison, D. E., 1982. Xanthan Gum-A Lyotropic, Liquid Crystalline Polymer and its Properties as a Suspending Agent. Society of Petroleum Engineers Journal, 22(4), 555-556.

3. Bourgoyne Jr, A. T., Millheim, K. K., Chenevert, M. E., and Young Jr, F. S., 1986. Applied drilling engineering. Volume 2.

4. Kelessidis, V. C., Maglione, R., Tsamantaki, C., and Aspirtakis, Y., 2006. Optimal determination of rheological parameters for Herschel-Bulkley drilling fluids and impact on pressure drop, velocity profiles and penetration rates during drilling. Journal of Petroleum Science and Engineering, 53(3), 203-224.

5. Casson, N., 1959. In reheology of dipersed system.

6. Khataniar, S., Chukwu, G. A., and $\mathrm{Xu}, \mathrm{H}$., 1994. Evaluation of rheological models and application to flow regime determination. Journal of petroleum science and engineering, 11(2), 155-164.

7. Fordham, E. J., Bittleston, S. H., and Ahmadi Tehrani, M., 1991. Viscoplastic flow in centered annuli, pipes, and slots. Industrial \& engineering chemistry research, 30(3), 517-524.

8. Menezes, R. R., Marques, L. N., Campos, L. A., Ferreira, H. S., Santana, L. N. L., and Neves, G. A., 2010. Use of statistical design to study the influence of CMC on the rheological properties of bentonite dispersions for water-based drilling fluids. Applied Clay Science, 49(1), 13-20.
9. Bailey, W. J., and Weir, I. S., 1998. Investigation of methods for direct rheological model parameter estimation. Journal of Petroleum Science and Engineering, 21(1), 1-13.

10. Robertson, R. E., and Stiff Jr, H. A., 1976. An improved mathematical model for relating shear stress to shear rate in drilling fluids and cement slurries. Society of Petroleum Engineers Journal, 16(1), 31-36.

11. Beirute, R. M., and Flumerfelt, R. W., 1977. An evaluation of the Robertson-Stiff model describing rheological properties of drilling fluids and cement slurries. Society of Petroleum Engineers Journal, 17(2), 97-100.

12. Gucuyener, I. H., 1983. A rheological model for drilling fluids and cement slurries. In Middle East Oil Technical Conference and Exhibition. Society of Petroleum Engineers.

13. Gücüyener, I. H., and Mehmetog, T., 1996. Characterization of flow regime in concentric annuli and pipes for yieldpseudoplastic fluids. Journal of Petroleum Science and Engineering, 16(1-3), 45-60.

14. Gücüyener, I. H., Celik, M., Turcan, H. H., Erkekol, S., Evin, S., Alp, B., and Özel, R., 2001. Application and Results of the KCL/Polymer Mud in Drilling Operations in Thrace Basin. In Proceedings of $13^{\text {th }}$ International Petroleum Congress and Exhibition of Turkey.

15. Herschel, W. H., and Bulkley, R., 1926. Measurement of consistency as applied to rubber-benzene solutions. In Am. Soc. Test. Proc., 26(2), 621-633.

16. Al-Zahrani, S. M., 1997. A generalized rheological model for shear thinning fluids. Journal of Petroleum Science and Engineering, 17(3-4), 211-215.

17. Bingham, E. C., 1922. Fluidity and plasticity (Vol. 2). McGraw-Hill Book Compny, Incorporated. 